\title{
Philosophy in the Present Context of Africa
}

\author{
Tsenay Serequeberhan
}

\begin{abstract}
The focus of the article is to explore the possibilities of philosophic discourse in the present postcolonial African situation. As indicated in the title, it will begin by exploring and laying out grosso modo, the character of philosophy as a discipline. It will then engage in examining, again broadly, Africa's present: the situation that has prevailed since the end of formal colonialism. Consequent on the two expositive presentations, the article will then indicate the role that philosophy can and should play in this situation. The aim is to explore the possible beyond the demise of colonialism in the hope of catching sight of a truly postcolonial future. The article is thus a concise articulation of the hermeneutical stance in contemporary African philosophy.
\end{abstract}

Keywords: colonised, Eurocentric, human, humanity, image

What I hope to do in this article $^{1}$ is to explore the role that philosophy can play in our present African situation. My chosen title commits me to two tasks: (1) laying out, broadly, the character of the discipline that goes by the name philosophy; and (2) exploring, again in broad outline, the present postcolonial condition of Africa. I will then spell out what role, in my view, philosophy can and should play in this our present postcolonial condition.

In Vocazione e responsabilità del filosofo, Gianni Vattimo points out that arguments in philosophy are discourses aimed at 'persuasion' and situated in the shared views of 'a collectivity' (Vattimo 2000: 71). He further observes: 'It becomes clear that it [philosophy] essentially concerns proposals for interpreting our common situation according to a certain line and starting from 
shared presuppositions' (ibid.). In such 'proposals' and deliberations we try to persuade each other by presenting arguments and citing authors we value and our counterparts in dialogue also value and appreciate. The authors we cite, furthermore, are not concerned with demonstrating that such and so is or is not the case based on indisputable facts (ibid.) but are themselves engaged in persuading each other and searching for shared interpretations of a 'common situation' (ibid.), which has become - in view of lived exigencies problematic and worthy of questioning.

Our persuasiveness is therefore not merely a rhetorical ploy directed at others but a reflexive and self-reflective critical exploration of our situation, the situation at hand, directed not only, or primarily, at others but more importantly at ourselves. This is how Socrates puts it, for example, in his last dialogical encounter with his friends, according to Plato, on the rather sombre day on which he drank the hemlock and satisfied the sentence of his polis - even as he vehemently disagreed with it. He states:

I am in danger at this moment of not having a philosophical attitude about this, but like those who are quite uneducated, I am eager to get the better of you in argument, for the uneducated, when they engage in argument about anything, give no thought to the truth about the subject of discussion but are only eager that those present will accept the position they have set forth. I differ from them only to this extent: I shall not be eager to get the agreement of those present that what I say is true, except incidentally, but I shall be very eager that I should myself be thoroughly convinced that things are so (Plato 1981: 129). ${ }^{2}$

Thus, to validate our respective interpretations of the 'common situation', we cite to each other interpretations and interpreters in whose esteem or appreciation we agree. From this it follows that the truth we try to maintain, and the way in which we maintain it, is along the lines of arguing for a stance, or a perspective, in view of certain accepted reference points in terms of which we can then pose the critical question, 'how can you still say this?' (Vattimo 2000: 72). In other words, asks Vattimo: 'Is it not perhaps true that the experience procured for you by a reading of Nietzsche (or of Kant, or of Hegel) impedes you from saying things that perhaps at one time you might have said and sustained?'(ibid.). That is, don't the insights secured in reading such and similar authors compel us 
to rethink or reconsider the presuppositions or prejudices (Gadamer 1982: $245-253)^{3}$ that ground our outlook?

The affirmative response to this rhetorical question takes for granted accord in our words and deeds and assumes rigour and consistency as indispensable for the practice of philosophy; a kind of reflection that incessantly assesses and reassesses itself in light of 'all that which happens in human reality' (Vattimo 2000: 52). Otherwise, the 'how can you still say this?' of philosophy, as Socrates patiently explains to Crito, would be 'in truth play and nonsense' (Plato 1981: 48).

In all of this, our efforts are aimed at validating and/or discarding our lived prejudices, our 'shared presuppositions', by calibrating and synchronising the line of sight that they make possible. For, as Hans-Georg Gadamer has insightfully observed: 'Prejudices are [the] biases of our openness to the world' (Gadamer 1966: 9). Philosophy is, therefore, focused on sifting our prejudgments or presuppositions - the prejudices we live by - in view of the shared possibilities of our lived present. Consequently, it stands in very close proximity to history; it is the reflective validation, always self-critical, of its time, its historicity. Conversely, the historicity in which a philosophic discourse finds itself furnishes the problems of concern and the context-background in which a philosophic discourse foregrounds its interpretations. As Gadamer puts it, the role of 'temporal distance', the role of history, is to allow 'those prejudices [i.e., presuppositions] that are of a particular and limited nature [to] die away' while making possible 'those that bring about genuine understanding' (Gadamer 1982: 266). Philosophy is thus a historically suffused interpretative querying and sifting of lived existence focused on - and open to - the possible in that which is.

This conception of philosophy, furthermore, is not a view that is idiosyncratic to Vattimo. It is the basic self-understanding of the practice of philosophy. In other words, as Hegel points out, 'philosophy . . . is its own time apprehended in thoughts' (Hegel 1967: 11). It is the critical-reflective and persuasive exploring of the viable conceptions and ideas, the prejudices or presuppositions, of its lived moment of time. Kant, referring to his own era as 'the age of criticism' notes that, 'everything must submit' to critical scrutiny and be 'able to sustain the test of a free and open examination, (Kant 1965: 9), which is, properly speaking, the practice of philosophy. This too, 
grosso modo, is what Nietzsche means when he states that 'this art of transfiguration is philosophy' (Nietzsche 1974: 35).

In sum, philosophy is the practice of reflectively exploring grounding concerns that originate in specific regions and histories. To speak of 'European or African' philosophy is to indicate the particular region-culture in and out of which 'a specific type of intellectual activity (the critical [interpretative] examination of fundamental problems)' is being undertaken (Towa 1991: 195). In like manner, the qualifiers contemporary, modern, ancient, and so forth, indicate the time period, or history (i.e., the historicity), in which this 'specific type of intellectual activity' is being practiced in engaging the exigencies and/or concerns of its lived moment of time. Indeed, as Antonio Gramsci has noted, 'History and philosophy are in this sense indivisible: they form a bloc' (Gramsci 1992: 345). And, within this 'bloc', philosophic effort is focused on exploring the layered and sedimented traces of history/life that constitute our existence and that have been collected 'without the benefit of an inventory' (ibid. : 324). ${ }^{4}$ The lived concerns of our temporal existence - our historicity - on the other hand, constitute the horizon of possibilities and supply the exigencies that agitate and/or occupy our philosophic-interpretative reflections. Now then, with this understanding in mind let us, again in broad strokes, look at our present African postcolonial condition.

The 1960s saw the achievement of independence in most of Africa. The 1970s witnessed the termination of Portuguese-NATO colonialism. And, the early 1990s - with the demise of Apartheid South Africa and the victorious conclusion of the Eritrean Independence Struggle - finalised the achievement of Africa's age-old struggle for political sovereignty. ${ }^{5}$ Now, it is important to keep in mind that, as it was occurring, this protracted process did not have universal acclaim. Indeed, as Gerald Caplan has pointedly observed:

In 1960, a resolution at the United Nations General Assembly calling for the independence of all colonies was opposed by every European colonial power - Britain, France, Portugal, Belgium and Spain - plus the US and South Africa (Caplan 2008: 34).

Thus, it was against the grain of the then established global political order, that is, against tremendous odds and at great cost, that independence was secured. This, however, should not be understood 
to mean that, with the attainment of independence, radical political agendas were instituted as the moving force of the Continent. To the contrary, in most cases, this arduous process was a process through which, directly and/or indirectly and under many guises, the substantive core of independence was eroded. Formal sovereignty, secured at great cost, was at the same time effectively emptied of anything but form. As Claude Ake explains:

With a few exceptions ... independence was not a matter of the nationalists' marshaling forces to defeat colonial regimes. More often than not, it was a matter of the colonizers' accepting the inevitable and orchestrating a handover of government to their chosen African successors ... who could be trusted to share their values and be attentive to their interests. This approach did not succeed in all places where decolonization was peaceful, much less where it was occasioned by revolutionary struggle. But on the whole, political independence in Africa was rarely the heroic achievement it was made out to be; it was often a convenience of deradicalization [sic] by accommodation, a mere racial integration of the political elite. (Ake 1996: 3-4)

In this manner, Africa, along with the rest of the formerly colonised world, that up to then had been excluded from history, reinserted itself into the actuality of historical existence. And the formerly colonising world, the West, best it could, relinquished to the newly independent states the absolute bare minimum in all aspects of international economics and politics which, to this day, it firmly controls. Grudgingly, and under duress, the West assented, while simultaneously manoeuvring to maintain its claimed cultural-spiritual superiority. Its hegemony, to this day, is sustained by those it 'trusted to share' its 'values and be attentive' to its 'interests'. In this way the stage was set for our postcolonial present, that is, our dismal postcolonial condition.

Indeed, as Edward W. Said has noted, 'the history of post-colonial states in Africa ... is a very sad history', which begins in a 'period of independence and liberation with a lot of hopes' (Said 1995:8) and which, in more cases than not, has ended in marginalisation and neo-colonial despair. For, while Africa has indeed reclaimed sovereignty over its territory, in large measure it failed to reclaim itself. More than in Asia or Latin America, this is the case in postcolonial Africa. As one of Sembène Ousmane's tragicomic characters confesses, in a rather lucid moment of angst: 
We are nothing better than crabs in a basket. We want the ex-occupiers place? We have it. . . Y Yet what change is there really in general or in particular? The colonialist is stronger, more powerful than ever before, hidden inside us, here in this very place. (Sembène 1976: 84)

This then is our postcolonial condition: how to purge the colonial residue that still controls, from 'inside us', our present. This is the internalised echo of colonial Europe's sense of history and human existence: the colonial enterprise which has become the lived selfawareness of the westernised segments of the formerly colonised territories. But what exactly does this mean? In this regard, as Cornelius Castoriadis explains, what the West asserts is,

not that it had discovered the trick of producing more cheaply and more quickly ... but that it had discovered the way of life appropriate to all human society. Fortunately for the Western ideologues, the unease they could have felt on this score was allayed by the haste with which the 'developing' nations [or, more accurately, the westernized ruling strata of these nations] try to adopt the Western 'model' of society. (Castoriadis 1991: 181-182)

Again, as Castoriadis further points out:

Factually speaking, the West has been and remains victorious - and not only through the force of its weapons: it remains so through its ideas, through its 'models' of growth and development, through the statist and other structures which, having been created by it, are today adopted [or more accurately, aped, mimicked, etc.] everywhere. (ibid.: 200-201)

Within this array of 'models' of growth and development', within this framework of concepts, ideas, and interpretations - that is, the prejudices and presuppositions - that constitute the paradigms of knowledge and of common sense which sustain Western global hegemony, Africa plays the part of a willing victim. In mimicry its ruling strata perpetuate its subjection. And so, beyond direct colonialism, the project of domination - which constitutes its practice endures in the servile imitative rule of Westernised Africa.

At the dawn of independence, Fanon had prophetically observed that, without eradicating the debilitating effects of colonialism and restructuring - to the measure of what it names - the actuality of independence, 'independence', in and of itself, could be nothing more than: 
a minimum of readaptation, some reforms at the summit [of power], a flag and, all down below, the undivided mass always [la masse indivise toujours] 'medievalized' [moyenâgeuse], which continues its perpetual [restless, nervous] movement. (Fanon 1961: 94)

In this context, as Chinua Achebe tells us, to the 'vast storehouse of lurid images' (Achebe 2000: 26--7) (i.e., the legacy of colonial writing on Africa) has been added the image of an innately incapacitated continent. Within this debilitating setup, and constantly nurtured by it, the myth of an inherently impaired 'darker' sector of humanity, incapable of doing for itself is sustained. The daily news (i.e., genocide, manmade famine, corruption, blood-diamonds, etc.) in an ongoing manner perpetuates and confirms this image of Africa as a continent wedded to perdition. Frozen/framed in this image, the Continent is seen as a perennial problem, incessantly testifying against itself.

In this regard, what should never be forgotten is that colonisation did not merely destroy the modes of life and thought through which precolonial Africa lived its existence. It constituted Africa as a servile appendage of the West. To this day, this heritage is held in place by its most tangible colonial legacy, the colonial-postcolonial state, that is, the colonial state apparatus run for and by Westernised Africa. In this manner, we are controlled by the heritage of our defeats. Not rooted in local conditions, the ministers and ministries of African governments are held in place by foreign props, lubricated by graft. 'Corruption', as Elizabeth Blunt, a BBC Africa analyst, tells us 'is costing the continent nearly $\$ 150 \mathrm{bn}$ a year' (Blunt 2002: 1). To date, and overall, this has indeed been the real palpable actuality of 'independence'.

Each African state has a flag which marks the geographic terrain within which westernised strata (Francophone, Anglophone, Lusophone, etc.) live colonial lifestyles. The vast majority, relegated to a wretched existence and frozen in discarded traditions, is seen as the refuse of history and held in check - as in colonial times - by violence. Disillusionment and desperation, in this situation, are the order of the day and the harsh memories of the colonial past are relatively dimmed. 'What was it all for?' thus becomes a rhetorical 'common-sense question'.

Instead of radically restructuring the political-economic situation - that is, the residue of the colonial past - in accordance with 
the slogans, programmes, and aspirations that directed the political and/or armed struggles that secured independence, Westernised Africa perpetuates colonial conditions as independence. Indeed, 'cette caste' as Fanon has noted, 'has done nothing other than to take over unchanged the legacy of the economy, the thought, and the institutions left by the colonialists' (Fanon 1961: 117). All this the West tacitly and silently applauds, sanctions, and vigorously in an ongoing manner - sustains utilising, to this end, differing forms of subterfuge. In fact, one could say that, overall, the foreign policy objectives of former colonial powers are aimed at economic dependence and political subservience - in the guise/mask of development aid.

In view of all the foregoing then, what role can philosophy play in the present context of Africa? Unlike the West, Africa experienced 'modernisation' not as the result of an organic internal process of historical-dialectical self-transformation, but of conquest. This was nothing more than the insertion of Africa into Europe's colonial economy (Nyerere 1998: 8). Our postcolonial present, in order to measure-up to what it names, must institute a reversal of this process. It must create a process of economic self-transformation that is democratically controlled - that is, directed, managed, and invested-in - at the grassroots level. A process responsive to the needs of those engaged in it and built on the precept that mindless 'imitation is suicide' (Emerson 1982: 8). To be true to what it claims, our postcolonial present has to be a period of time in which independence is consolidated by the imaginative and selfreliant transformation of the formerly colonised territory, aimed at its economic viability and the establishment of participatory forms of democratic self-rule.

The articulation of this worthy project - on the level of reflection - is the task of philosophy in Africa. This means probing, exploring, questioning, and undermining the prejudices and presuppositions that constitute the 'models of growth and development' that, on the level of ideas and concepts, perpetuate the colonial past as independence. It concurrently also means seeking the sense and meaning of independence and, in this process, conceptually articulating the way or ways of actualising its possibility. For, as Said has noted, independence was nothing more than 'a convenient starting point from which the real work, the hard work, might begin' (Said 
2000: 379). This 'convenient starting point' was taken as the final moment of Africa reclaiming itself. And so, the 'real work, the hard work' subsequent to the ending of colonial rule (i.e., the physical expulsion of the coloniser) was never undertaken. The termination of colonial rule ought to have unleashed, to the measure of what it named (i.e., independence), the self-transformation of the formerly colonised. Without such a transformation, in the words of Sembène, we are nothing more than 'crabs in a basket'. On the level of reflection, this 'real work' is the critique of the Occident in tandem with the sifting and sieving of our traditions - European and African - aimed at a new synthesis: 'a selective analysis of the values of the culture within the framework' (Cabral 1973: 52) of our present postcolonial condition.

We, those of us engaged in the practice of African philosophy, must reimagine the ideals that fuelled the political and armed struggles for independence - in and out of the context of the present - and, in so doing, formulate the concepts and ideas that can help actualise them. For, 'the present', as José Ortega y Gasset tells us, 'is a mere pretext for the existence of the past and of the future, the juncture where both derive meaning' (Gasset 1967: 14). The challenge is thus to articulate counter-discourses aimed at inventing novel ways of comprehending social-political existence and, in this way, sensibly appropriating our past in view of a desirable future - in firmly contesting the established subservience of 'the present . . . the juncture where both [i.e., past and future] derive [their] meaning' (ibid.). Out of such inventive efforts, we might be able to glimpse the possibility of a truly postcolonial existence. In such inventive reflective efforts, what is reclaimed, on the level of thought and reflection, is the verve of life that once was the anticolonial struggle.

To 'invent' here means to come upon - to discover from within the limits and needs of the present - the way, or ways, for authenticating our independence. Like scientists engaged in 'extraordinary science' (Kuhn 1970: 86-87), our only concern in this will be to see 'what works', what can help us overcome our postcolonial stasis, that is, our postcolonial condition. To be sure, African philosophy can also go on documenting the traditional worldviews, or 'philosophies', of ethnic Africans (Igbo, Yoruba, etc.) or it can also engage in what has come to be known as 'Sage philosophy'. This would indeed be interesting but not very serious! 
In Africa, as elsewhere, philosophy has never been concerned with 'the interesting' and/or 'the exotic' as such - but with the concrete problems or exigencies of its time. In other words, for example, if Socrates obsessed about piety, courage, justice, and similar value-terms, it was because the Peloponnesian War (431404 BCE), among other things, spearheaded by the conflict of Athens and Sparta, rendered established usages and accepted notions questionable. This was the basic exigency that stimulated his dialogical efforts, focused on 'the manner of one's life' (Plato 1974: 4) in critical relation with the wisdom of his past (i.e., Simonides), confronting the folly of his present (i.e., Thrasymachus) and in view of a desirable possibility. One need not endorse every aspect of Plato's ideal state to acknowledge the way he engaged its theoretic possibility.

The importance of all of this derives from the understanding that, at the end of the day, what really matters in the practice of African philosophy, is the character of the lived existence we strive towards and help bring about. We, too, in other words, are concerned with 'a whole way of living' (ibid.: 18). Today, even as the odious memories of the colonial period recede into the past, the prejudices and presuppositions that 'established [the] hierarchy of Master and Servant' (Marcuse 2007: 10) in colonial times are being re-established anew as the actuality of the present and of our possible future. Our present challenge is thus to persuasively think through the questioning of this 'hierarchy', of the prejudices and presuppositions, which threaten to perpetuate the colonial past as our future. This is the core concern that moves - and ought to move - our think in African philosophy. For 'the present', as we noted earlier with Ortega is 'the juncture where both' the past and the future 'derive [their] meaning'.

Tsenay Serequeberhan is professor of philosophy at Morgan State University. Originally from Eritrea, he is, in Anglophone African philosophy, a pioneer proponent of African philosophical hermeneutics. His research, focused on social-political philosophy, broadly conceived, is aimed at exploring thematic confluences in the discourses of African/Africana and Continental philosophy. In his most recent book, Existence and Heritage (SUNY Press, 
2015), as in his previous work, Serequeberhan is focused on exploring the possibilities for ameliorating the character of human existence in view of our contemporary postcolonial world situation. E-mail: tsenay.serequeberhan@morgan.edu

\section{Notes}

All emphasis in the original unless otherwise indicated.

1. Some of the thoughts expressed in this article overlap with formulations and conceptions articulated in the first chapter of my most recent (2015) book, Existence and Heritage, New York: SUNY Press.

2. To be 'convinced that things are so' is to be cognisant of the truth of what shows itself. In this regard, as Karl Jaspers points out, for Socrates: 'He who becomes a true man' does so in being open and susceptible to the openness of his being to that which shows itself and in this 'becomes a true citizen', The Great Philosophers (New York: Harcourt, Brace \& World, Inc., 1962, p. 17). Dialogical questioning is thus for Socrates the avenue, or way, for becoming 'a true man' and hence 'a true citizen'. For the polis (i.e., the political community) is singularly or inherently peculiar to the being that is human.

3. On the term 'prejudice', see Hans-Georg Gadamer, Truth and Method (New York: Crossroad, 1982), pp. 245-253.

4. The standard English translation on the indicated page (i.e., p. 324) reads 'without leaving an inventory'. The original, which I cite reads, 'senza beneficio d'inventario', Quaderni Del Carcere, edited by Valentino Gerratana, vol. 2 (Torino, Italia: Giulio Einaudi, 1975), p. 1376.

5. The Eritrean Independence Struggle (1961-1991) was a struggle for national liberation, fought by proxy, against US imperialism and Soviet hegemony. To see it as merely an inter-African squabble is to betray one's naïveté on questions of big power politics.

\section{References}

Achebe, C. 2000. Home and Exile. New York: Anchor Books.

Ake, C. 1996. Democracy and Development in Africa. Washington, DC: The Brookings Institution.

Blunt, E. 2002. 'Corruption costs Africa billions'. BBC News, 18 September, http://news.bbc.co.uk/2/hi/africa/2265387.stm

Cabral, A. 1973. Return to the Source. New York: Monthly Review Press.

Caplan, G. 2008. The Betrayal of Africa. Toronto: Groundwood Books.

Castoriadis, C. 1991. Philosophy, Politics, Autonomy. New York: Oxford

University Press.

Emerson, R. W. 1982. 'Self-Reliance'. In L. Ziff (ed), Selected Essays. New York: Penguin Books.

Fanon, F. 1961. Les damnés de la terre. Paris: François Maspero. 
Gadamer, H-G. 1966 (1967). 'The Universality of the Hermeneutical Problem'. In D.E. Linge (ed), Philosophical Hermeneutics. Trans. D. E. Linge. Berkeley: University of California Press.

Gadamer, H-G. 1982. Truth and Method. New York: Crossroad.

Gramsci, A. 1992. Prison Notebooks. Ed. and trans. Q. Hoare and G. Nowell Smith. New York: International Publishers.

Gramsci, A. 1975. Quaderni Del Carcere. Vol. 2. Ed. V. Gerratan. Torino, Italia: Giulio Einaudi.

Gasset, J. O. 1967. The Origin of Philosophy. Trans. T. Talbot. New York: W.W. Norton \& Co., Inc.

Hegel, G. W. F. 1967. Philosophy of Right. Trans. T.M. Knox. New York: Oxford University Press.

Kant, I. 1965. Critique of Pure Reason. Trans. by N.K. Smith. New York: St. Martin's Press.

Kuhn, T. S. 1970. The Structure of Scientific Revolutions, 2nd ed. Chicago, IL: University of Chicago Press, 86-87.

Marcuse, H. 2007. 'The Individual in the Great Society'. In A. Feenberg and W. Leiss (eds), The Essential Marcuse. Boston, MA: Beacon Press.

Nietzsche, F. 1974. The Gay Science. Trans W. Kaufman. New York: Vintage Books.

Nyerere, J. K. 1998. 'Africa: The Current Situation', African Philosophy 11 (1) June: 8.

Plato. 1974. Republic. Trans. G.M.A Grube. Indianapolis: Hackett Pub. Co.

Plato. 1981. 'Phaedo'. In Plato Five Dialogues, trans G.M.A. Grube. Indianapolis: Hackett.

Said, E.W. 1995. 'Never Just a Blind Supporter'. Interview given to Imad Musa in Palestine Report, no. 24.

Said, E. W. 2000. Reflections on Exile and Other Essays. Cambridge, MA: Harvard University Press.

Sembène, O. 1976. Xala. Chicago, IL: Lawrence Hill Books.

Towa, M. 1991. 'Conditions for the Affirmation of a Modern African Philosophical Thought'. In T. Serequeberhan (ed). African Philosophy: The Essential Readings, Trans A. Gashaw. New York: Paragon House.

Vattimo, G. 2000. Vocazione e responsabilità del filosofo [The Vocation and responsibility of the philosopher]. Genoa: Il Melangolo. 